\title{
Artichoke as a Tool to Natural Antioxidants for Lowering Diabetics and Hypolipidemia Parameters
}

\author{
Fizah M. M. Al-Subhi ${ }^{1}$
}

\begin{abstract}
The present study was carried out to evaluate the different parts of the artichoke plant (leaves and head) and the effect of their extracts $(200,400$ and $600 \mathrm{mg} / \mathrm{kg}$ body weight rat) as natural antioxidants on hypercholesterolemia and hyper diabetic rats. Chemical composition, fatty acids analysis, free phenolic acids and flavonoids compounds were determined and their bound of them. The results showed that the higher amount of crude protein and the lower in crude fiber were recorded in the

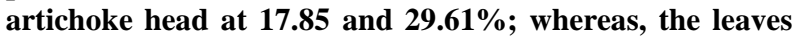
was recorded at $9.54 \%$ in protein and the highest amount of crude fiber was at $32.41 \%$. The artichoke (head) showed a higher content of free total phenolic compounds (14.16 $\mathrm{mg} / \mathrm{g}$ dry weight) followed by the artichoke (leaves) which contained only $9.06 \mathrm{mg} / \mathrm{g}$ dry weight. On the other hand both leaves and head parts of the artichoke showed a lower content of the bound phenolic compounds. The main compounds in the identification of fatty acids were palmitic (16:0), oleic (18:1 n-9) and linoleic (18:2 n-6) acids respectively in the different parts of artichoke. At the end of the biological experiments for four weeks, the results showed that the artichoke head had a significant lowering effect on lipid parameters and serum glucose in hypercholesterolemia and hyperdiabetic rats followed by artichoke leaves. These are caused by the high amounts of antioxidants in the artichoke head and a low content in crude fiber; whereas, the artichoke leaves had the highest content in crude fiber and low in natural antioxidants. Therefore, it may be recommended that feeding with the different parts of artichoke are beneficial and a healthy food, lowering diabetics and hypolipidemic pattern.
\end{abstract}

Keywords: Artichoke, phenolic acids and flavonoids compounds, diabetes and hypolipidemic.

\section{INTRODUCTION}

Artichoke belonging to the family Asteraceae is an herbaceous perennial crop (Bianco, 2005). Recently, a renewed and growing interest in the artichoke with a focus on new uses as a functional food has been observed Lattanzio et al. (2009). Artichoke is commonly grown for its large massive inflorescences, called capitula or heads. Artichoke is a rich source of bioactive phenolic compounds with edible fleshy leaves (bracts) and receptacle, which constitute an essential

DOI: 10.21608 /ASEJAIQJSAE.2020.94866

${ }^{1}$ General Nutrition, Family Education Department,

Collage of Education, Umm Al-Qura University, Saudi Arabia.

Fmsubhi@uqu.edu.sa ----- Dr.faiza428@gmail.com

Received May 05, 2020, Accepted, , June 10, 2020. component of the Mediterranean diet (Lattanzio, 1982). Artichoke can be eaten as a. fresh, canned, or frozen vegetable (Efterpi et al., 2012). This plant has been used in folk medicine since the Roman period for its health benefits primarily due to the high content of phenolic compounds and inulin (Sonnante et al., 2007; Lattanzio et al., 2009 and Pandino et al., 2011).

Phenolic compounds are very important substances for human nutrition as they are involved in the prevention of coronary disorders; osteoporosis, diabetes mellitus, cancer and neurodegenerative diseases of Clifford and Brown (2006). In addition, the leaves which are rich in phenolic compounds are used in herbal medicine and are known for their beneficial and therapeutic effects (Fratianni et al., 2007).

Extracts from artichoke have been used for hepatoprotection (Adzet and Carlos 1987). Among the common edible plants, artichoke is a rich source of dietary anti-oxidants; therefore it could be used in phytopharmaceutical applications (Ceccarelliet al., 2010). The edible parts of artichoke plants are the large immature flowers harvested in the early stages of their development, which, depending on the variety and harvest time, represent about 30-40 \% of their fresh weight. Since only the central portion of the capitula is eaten, the ratio of the edible fraction to the plant's total biomass is very low, ranging from 15 to $20 \%$ of the total biomass produced. This ratio further decreases and is also considered by Lattanzio (1982) to add to the total biomass provided by irregular shoots which are often removed as part of common cultural procedures.

In many in-vivo and in-vitro trials, the pharmacological properties of artichoke flower heads are well established for the treatment of hepato-biliary dysfunction, dyspeptic syndromes, gastric disorders and inhibition of biosynthesis of cholesterol and low-density lipoproteins (LDL) oxidative agents responsible for arteriosclerosis and coronary heart disease (Lattanzio et al., 2009). Artichoke leaf extracts fed on rats with high cholesterol diet reduced serum lipids, as well as hepatic and cardiac oxidative stress (Kucukgergin et al., 2010). Wild artichoke extracts fed to aged rats seemed to exert cardio protective effects (Kucukgerginet al., 2010). 
Medicinal plants especially artichoke (CynarascolymusL.) leaves have long been used effectively for treating a variety of diseases in the world. Artichoke is abundant in natural antioxidants and contains derivatives of caffeoylquinic acid (cynarine and chlorogenic acids) and flavonoids such as luteolin and apigenin (Llorach et al., 2002 and Wang et al.., 2003).

Artichoke has been reported to substantially reduce serum cholesterol in hypercholesterol subjects (Joy and Haber, 2007) and to decrease the formation of reactive oxygen species (ROS), lipid peroxidation and in vitro oxidation of low-density lipoproteins (Zapolska-Downar et al., 2002). Changes in serum lipid and lipoprotein levels, particularly hypercholesterolemia, lead to a variety of chronic diseases, including coronary heart disease and atherosclerosis (Gould et al., 2007and McKenney, 2001).

A variety of experiments have been performed on plant flavonoids that could be helpful in decreasing the risk of obesity and its complications (Andersen et al., 2010 and Mulvihill and Huff, 2010). Artichoke (Cynarascolymus L) in this respect is introduced as new lipid-lowering therapeutic agent (Joy and Haber, 2007 and Küskü-Kirazet al., 2010). Artichoke leaves were used in traditional medicine for a variety of diseases, especially hyperlipidemia.

Hypolipidemic effects of artichoke have been reported in laboratory and therapeutic trials (Shimoda et al., 2003 and Joy and Haber, 2007). Artichoke is also made of natural bioactive ingredients, i.e. caffeic acid, chlorogenic acid, cynarin and luteoline. These components minimize the production of reactive oxygen species (ROS), lipid peroxidation and low density lipoprotein oxidation (LDL) by in vitro experiments (Zapolska-Downaret al., 2002, Wanget al., 2003 and Juzyszyn et al., 2008). Therefore, these properties of artichoke warrant its application in traditional medicine. The globe artichoke (Cynaracardunculus var. scolymus) is a variety of a species of thistle cultivated as a food. The edible portion of the plant consists of the flower buds before the flowers come into bloom. The budding artichoke flower-head is a cluster of many budding small flowers (an inflorescence) together with many bracts, on an edible base. Once the buds bloom, the structure changes to a coarse, barely edible form. Another variety of the same species is the cardoon, a perennial plant native to the Mediterranean region (Rottenberg and Zohary 1996).

Therefore, the aim of this study was to evaluate the different parts (leaves and head) of the artichoke and to determine the effects of artichoke extracts of its different parts at 200, 400 and $600 \mathrm{mg} / \mathrm{kg}$ body weight ratios on the serum glucose, total lipids, total cholesterol, triglycerides and high and low density lipoprotein- cholesterol in the serum.

\section{MATERIALS AND METHODS}

\section{Materials:}

Fresh artichoke (Cynarascolymus L.) was obtained from the local market of Holy Makkah, Saudi Arabia. The leaves were separated from the plant and then the fresh samples of artichoke (leaves and head) were washed and dried in an oven at $50^{\circ} \mathrm{C}$ for two days, ground, sealed in polypropylene bags, and stored at $4^{\circ} \mathrm{C}$ until analysis.

The standards chemicals such as phenolic acids and flavonoid derivatives have been obtained from Sigma Chemical Co. (St. Louis, Missouri, USA) and HPLCgrade solvents such as chloroform, methanol and acetic acid have been purchased from Merck (Germany).

\section{Methods:}

Determination of the proximate composition of the dried samples:

Ash, total carbohydrate, crude protein, crude fiber and fat for the dried leaves and the artichoke head were analyze according to AOAC (2010).

\section{Sampling extraction of free and bound phenolic compounds:}

According to Sosulski et al. (1982) methods, phenolic compounds were extracted into free and bound phenolics, with a minor modification by Adom and Liu (2002). Through continuous shaking, free phenolic flour compounds $(1 \mathrm{~g}$ were extracted with $10 \mathrm{ml}$ of $80 \%$ chilled ethanol for $20 \mathrm{~min}$. The residue was re-extracted twice after centrifugation at $2500 \mathrm{~g}$ for $10 \mathrm{~min}$ and all supernatants were mixed and evaporated under reduced pressure to dryness. Instead, the free phenolic compounds were processed at $-40^{\circ} \mathrm{C}$ till their use. The residue from the free phenolic compound extraction was directly hydrolyzed at $20 \mathrm{ml}$ of $2 \mathrm{~N} \mathrm{NaOH}$ for $90 \mathrm{~min}$ with a continuous shaking at $60^{\circ} \mathrm{C}$ (Yeh et al., 1980). The hydrolysate was acidified to $\mathrm{pH} 2(6 \mathrm{~N} \mathrm{HCl})$ and centrifuged to isolate cloudy precipitation. The released phenolic acids were extracted with ethyl acetate and evaporated to dryness, dissolved and filled up to $10 \mathrm{ml}$ of methanol and stored at $-4^{\circ} \mathrm{C}$ before use. Complete free and bound phenolic content in samples was expressed as mg equivalent gallic acid (GAE) / g dry weight. Samples were analyzed in triplicates.

\section{Free and bound of total flavonoids content in artichoke:}

Total flavonoids content (TFC) of free and bond phenolic extracts of the different parts (leaves and head) of artichoke was spectrophotometrically determined by the aluminium chloride method using quercetin as a standard (Zhishen et al., 1999). In $10 \mathrm{ml}$ volumetric 
flask, $4 \mathrm{ml}$ of distilled water adding to one $\mathrm{ml}$ of extract or standard solution (quercetin, 20-120 mg / 1) has been added. To the flask $0.3 \mathrm{ml} 5 \%$ NaNO2 was added and after $5 \mathrm{~min} 0.3 \mathrm{ml} 10 \% \mathrm{Al} \mathrm{Cl3}$ was added. At 6 th $\mathrm{min}$, $2 \mathrm{ml} 1 \mathrm{M} \mathrm{NaOH}$ were added and the total volume was made up to $10 \mathrm{ml}$ with distilled water The solutions were well mixed, and spectrophotometer (Unicum UV 300) was used to measure the absorbance against prepared reagent blank at $510 \mathrm{~nm}$. Total flavonoids were expressed as equivalents of $\mathrm{mg}$ quercetin $(\mathrm{QE}) / \mathrm{g}$ fresh weight. Samples were analyzed in triplicates.

\section{Fractionation and identification of phenolic compounds:}

The polyphenolic compounds of artichoke extracts were fractionated and identified for phenolic compounds by HPLC, according to the method described by Pinto et al. (2008). Identification of individual phenolic compounds was performed on Hewlett- Packard HPLC (Model 1100), using a hypersil C18 reversed- phase column $(25 \times 4.6 \mathrm{~mm})$ with $5 \mu \mathrm{m}$ particle size. Phenolic compounds were identified by comparing retention times and UV-VIS spectra with those of pure standards and the range of calibration curves.

\section{Fatty acid composition in different parts of artichoke:}

Fatty acid methyl esters were prepared by saponification of the sample lipid contents with sodium hydroxide $0.5 \mathrm{~mol} / \mathrm{L}$ (in methanol), followed by methylation with triboronfluoride (12.0 ml BF3 in 100.0 ml methanol) according to Joseph and Ackman (1992) and separated by gas chromatography (GC) using a Thermo 3300 gas chromatograph equipped with a flame ionization detector (FID) and a fused-silica CP-7420 (SELECT FAME) capillary column $(100 \mathrm{~m} \times 0.25 \mathrm{~mm}$ cyanopropyl).

Fatty acids have been identified by comparing retention times to those of normal methyl esters. Quantification of fatty acids (FAs) was conducted using tricosanoic acid methyl ester as an internal method in conjunction with Joseph and Ackman (1992).

\section{Extraction of different parts of artichoke:}

Artichoke fresh leaves and head were separated and cleaned, it was blended mechanically with $2000 \mathrm{ml}$ distilled water then filtered through two-layer of cheese cloth, and the resultant residue was re-dissolved in 1000 $\mathrm{ml}$ distilled water by using magnetic stirrer for $1 \mathrm{~h}$. The later aqueous extract was added to the first one. The combined aqueous extract was condensed in rotary evaporator under vacuum then lyophilized and stored at $4^{\circ} \mathrm{C}$ until further use. Lyophilization was conducted by using Freeze-Dryer Lyophilizer, Virtis, USA. The method of extraction was carried out according to Jimenez-Escriget al. (2003).

\section{Biological experiments:}

Male albino rats Sprague Dawley strain (48 animals) weighing 170- $180 \mathrm{~g}$ were housed in individual cages with screen bottoms and fed on basal diet for one week. It consisted of casein $10 \%$, corn oil $10 \%$, cellulose $5 \%$, salt mixture $4 \%$, vitamin mixture $1 \%$ and corn starch $70 \%$. The salt mixture and vitamin mixture used were that proposed by AOAC (2010).

After eight days of feeding on the basal diet, rats were divided into two groups. The first group (6 rats) was fed on the basal diet for four weeks (30 days) and regarded as negative controls. The second main group (42 rats) was fasted overnight and injected into the leg muscle $(5 \mathrm{mg} / 100 \mathrm{~g}$ body weight) with streptozootocin (dissolved in a $0.1 \mathrm{M}$ citric acid buffer and adjusted at $\mathrm{pH}$ 4.5) to induce hyperdiabetic and hypercholesterolemic rats according to Madar (1983). The second main group was split into seven subgroups after $48 \mathrm{hr}$. of injection (6 rats for each). The first one (6 rats) was continued to be fed on basal diet and considered as positive control. The second to four subgroups (6 rats for each) were fed on the basal diet and they were fed with $2 \mathrm{ml}$ orally per day from artichoke leaves extract at three $\mathrm{ml}$ doses (200, 400 and $600 \mathrm{mg} / \mathrm{kg} \mathrm{b.wt}$.); and also, the five to seven subgroups (6 rats for each) were fed on the basal diet and they were fed with $2 \mathrm{ml}$ orally per day from artichoke head extracts at three doses $(200,400$ and $600 \mathrm{mg} / \mathrm{kg}$ b.wt.).

Each rat was weighed in every two days and the consumption of food was calculated. At the end of the treatment period (4 weeks), blood samples were taken from the orbital plexus and centrifuged at $3000 \mathrm{rpm}$ to obtain serum. After C until their analyses. Serum $\square$ that, the sera were kept on a deep-freezer at -20 glucose, total lipids, total cholesterol and triglycerides were determined according to Tietz (1986), knight et al. (1972), Allain et al. (1974) and Fossati and Prencipe (1982), respectively. High and low density lipoproteincholesterol in serum was determined according to Burstein (1970) and Fruchart (1982).

\section{Statistical analysis:}

The data obtained in the present study was analyzed by ANOVA. For all analyses, when a significant difference $(p \leq 0.05)$ was detected in some variable, the data means test was applied to evaluate the difference between the samples. The results were analyzed with the aid of the software SAS System for Windows SAS (2008). 


\section{RESULTS AND DISCUSSION}

\section{Chemical compositions of different part in artichoke:}

Results in Table (1) showed that the protein content of the artichoke leaves and heads with the highest amount of crude protein was recorded for the heads at $17.85 \%$ followed by the leaves recorded at $9.54 \%$ successively. These results are in agreement with the results of Hosseinzadeh et al. (2013) who found that, the protein content of artichoke leaves was in the ranged from 8.05 to $12.35 \%$. However, it was Lutz et al. (2011) who found that the protein content of artichoke heads was ranged from 15.96 to $18.25 \%$.

The fat content of the different parts of artichoke is also shown in the same Table and the results reported that a significant difference was shown for the fat content between leaves and head.

Such findings are consistent with the results of Hosseinzadeh et al. (2013) which found that the fat content of artichoke leaves ranged from 1.6 to $2.3 \%$ in dry wt. Basic. In the meantime, Jimenez-Escriget al. (2003) reported that the fat content of artichoke heads was only $1.69 \%$. Concerning the crude fiber content for artichoke significant differences could be shown among all the samples. The highest amount of fiber was for the leaves $(32.41 \%)$. The lowest amount was recorded for the heads $(29.61 \%)$. Results of the ash content of the leaves and head of artichoke a significant difference was recorded at 9.52 and $7.48 \%$, respectively. These results are in accordance with the results of Lutz et al. (2011) who estimated that the contents of artichoke heads were 7.04\%. However, Hosseinzadeh et al., (2013) reported that the ash content of artichoke leaves was $9.01 \%$. Percentage of overall carbohydrate (d.w) of artichoke was of significant difference amount of total carbohydrates and it was recorded for the leaves and head at 46.09 and $42.70 \%$, respectively.

Total phenolic and total flavonoids content of free and bound of artichoke:

Data presented in Table (2) indicated that artichoke (head) showed a higher free total phenolic content of FTPC (14.16 mg / g DW) followed by artichoke (leaves) containing only $9.06 \mathrm{mg} / \mathrm{g} \mathrm{DW}$. At the other side, both the leaves and the head parts of artichoke displayed a lower concentration of bound phenolic compounds (5.35 and $4.20 \mathrm{mg} / \mathrm{g}$ DW, respectively). Previous studies showed that the artichoke (head) contained higher amount of phenolic compounds along with higher amount of minerals and dietary fibers. As a phenolic role, the artichoke (head) should have higher free radicals scavenging activity than the artichoke (leaves), and was supported by Perez-Garcia et al.'s tests in (2000) who found that the nutritional and medicinal properties of both the leaves and the head are related to their unique chemical composition, which includes high levels of polyphenol and inulin. Lattanzio, et al. (2009) found that artichoke by-products are very rich in phenolic compounds and can therefore be considered as functional foods.

In addition, the total content of free and bound phenolic extracts of artichoke leaves and head in flavonoids (TFC) is shown in Table (2). The overall content of the free phenolic extracts with flavonoids was higher than the bound phenolic extracts.

Table 1. Proximate composition in artichoke parts (g/100g dry weight basis)

\begin{tabular}{lcc}
\hline Chemical analysis & Leaves (bracts) & Head (capitula) \\
Crude protein & $9.54 \pm 0.21^{\mathrm{b}}$ & $17.85 \pm 0.22^{\mathrm{a}}$ \\
Crude fat & $2.34 \pm 0.06^{\mathrm{a}}$ & $1.56 \pm 0.05^{\mathrm{b}}$ \\
Crude fiber & $32.41 \pm 0.24^{\mathrm{a}}$ & $29.61 \pm 0.11^{\mathrm{b}}$ \\
Ash content & $9.52 \pm 0.18^{\mathrm{a}}$ & $7.48 \pm 0.14^{\mathrm{b}}$ \\
Total carbohydrates & $46.09 \pm 0.44^{\mathrm{a}}$ & $42.70 \pm 0.13^{\mathrm{b}}$ \\
\hline
\end{tabular}

a,b Mean in the same row with different superscript differ significantly at $\mathrm{p} \leq 0.05$.

Table 2. Total phenolic and total flavonoids content of free and bound methanolic extracts of the different parts of artichoke

\begin{tabular}{lcc}
\hline Analysis & Leaves $\mathbf{~ m g / g}$ & Head $\mathbf{~ m g / g}$ \\
\hline Free phenolics & $9.06 \pm 0.06^{\mathrm{b}}$ & $14.16+0.08^{\mathrm{a}}$ \\
Bound phenolics & $5.35 \pm 0.08^{\mathrm{a}}$ & $4.20 \pm 0.07^{\mathrm{b}}$ \\
Free total flavonoids & $5.91 \pm 0.12^{\mathrm{b}}$ & $9.85 \pm 0.12^{\mathrm{a}}$ \\
Bound total flavonoids & $2.17 \pm 0.15^{\mathrm{b}}$ & $4.06 \pm 0.11^{\mathrm{a}}$ \\
\hline
\end{tabular}

$a, b$ Mean in the same row with different superscript differ significantly at $p \leq 0.05$ 
The total flavonoids concentrations of free and bound phenolic in artichoke head extracts were significantly higher ( 9.85 and $4.06 \mathrm{mg} / \mathrm{g} \mathrm{DW})$ when compared to artichoke leaves (5.91 and $2.17 \mathrm{mg} / \mathrm{g} \mathrm{DW})$.

\section{Identification of phenolic compounds for the dried artichoke parts:}

The phenolic compounds of the artichoke parts extracts were identified by HPLC, results are shown in Table (3). Phenolic compound 5-o-Caffeoylquinic acid (Chlorogenic acid) was found to be in high concentration $(\mathrm{mg} / 100 \mathrm{~g}$ dried sample) for the head which was recorded at $5.1021 \mathrm{mg} / 100 \mathrm{~g}$; meanwhile it was in low percentage for leaves that recorded at $0.7145 \mathrm{mg} / 100 \mathrm{~g}$.

The phenolic compound 1, 3-di-o-caffeoylquinic acid (cynarin) was contained in lower amounts than the chlorogenic acid, but also in greater quantities than 1,5di-o-caffeoylquinic acid in the artichoke samples under investigation. Shen et al. (2010) stated that the three compounds (5-o-caffeoylquinic acid (chlorogenic acid), 1, 3-di-o-caffeoylquinic acid (cynarine) and 1,5-di-ocaffeoylquinic acid are the main active compounds in artichoke, and are considered to be responsible for their antiatherogenic action. The caffeoylquinic acids are natural antioxidants with potential health benefits in the sense of inhibiting cancer growth, aggravated by the presence of reactive oxygen species according to Fukumoto and Mazza (2000). The phenolic compound apignin was contained in limited amounts for either leaves or heads of the two artichoke varieties. Justesen and Knuthsen (2001) and Pandino et al. (2013) reported that apignin is a compound rarely found in the plant kingdom that can only be found in certain herbs and vegetables. Luteolin phenolic compound was also found in two varieties of artichoke in leaves and heads. Pandino et al. (2013) and Kukic et al. (2008) reported that, luteolin are of interest since they show antimicrobial activity and inhibit cholesterol synthesis.

\section{Fatty acid composition in dried artichoke parts:}

Table (4) shows the ten main fatty acids which were detected in dried artichoke parts, four as the sum of saturated fatty acids (SFAs), two as the sum of monounsaturated fatty acids (MUFAs) and four as the sum of polyunsaturated fatty acids (PUFAs) (two n-6; two n-3). The main compounds in the SFA, MUFA and PUFA groups were palmitic (16:0), oleic (18:1 n-9) and linoleic (18:2 n-6) acids respectively. Alpha-linolenic acid (18:3 n-3) was also a significant proportion of PUFA content.

\section{Biological experiments:}

Effect of the different parts of artichoke extract on initial, final body weight and feed efficiency ratio in diabetic and cholesterolemic rats:

The results from Table (5) indicated that the effect of the different artichoke on initial, final body weight and feed efficiency ratio in diabetic and cholesterolemic rats. From the results it could be observed that the normal negative control group was fed on the basal diet had the highest in final body weight (194.5 g, increased in gain body weight $27.0 \mathrm{~g}$ ) and feed efficiency ratio $(5.84 \%)$ at the end experimental period (four weeks). While, the positive control group fed on the basal diet slightly significantly increased in the final body weight (177.0 g increased $6.7 \mathrm{~g}$ about initial body weight) and the feed efficiency ratio was $1.92 \%$. Meanwhile, the rat groups fed on leaves and head artichoke extracts orally per day at levels $600 \mathrm{mg} / \mathrm{kg}$ was observed with no significant changes in the final body weight and total food intake between them. It means that the rats fed on the different parts from artichoke at ratio $600 \mathrm{mg} / \mathrm{kg}$ did not affect the food intake and body weight.

Table 3. Phenolic compounds (mg/100 g) for dried artichoke parts

\begin{tabular}{lcc}
\hline \multirow{2}{*}{ Phenolic compounds } & \multicolumn{2}{c}{ Artichoke parts } \\
\cline { 2 - 3 } & Leaves & Head \\
\hline 5-o-Caffeoylquinic acid (Chlorogenic) & 0.7145 & 5.1021 \\
1,3-di-o-Caffeoylquinic acid (Cynarin) & 1.2823 & 0.4792 \\
1,5-di-o-Caffeoylquinic acid & 0.1136 & 0.1516 \\
Apignin & 0.1046 & 0.1101 \\
Luteolin & 0.0224 & 0.1384 \\
Caffeic acid & 0.1086 & 0.1102 \\
Salicylic acid & 0.1202 & 0.1297 \\
Gallic acid & 0.1015 & 0.1157 \\
Coumarin & 0.1018 & 0.1128 \\
Ferulic acid & 0.0534 & 0.1151 \\
Narirutin & 0.0215 & 0.1175 \\
\hline
\end{tabular}


Table 4. Fatty acid quantification $(\mathrm{mg} / 100 \mathrm{~g})$ for dried artichoke parts

\begin{tabular}{lcc}
\hline \multirow{2}{*}{ Fatty acids composition } & \multicolumn{2}{c}{ Artichoke parts } \\
\cline { 2 - 3 } & \multicolumn{1}{c}{ Leaves } & Head \\
\hline $16: 0$ (Palmitic acid) & $229.95 \pm 20.94^{\mathrm{b}}$ & $2303.58 \pm 146.02^{\mathrm{a}}$ \\
$18: 0$ (Stearic acid) & $13.37 \pm 2.27^{\mathrm{b}}$ & $297.20 \pm 15.08^{\mathrm{a}}$ \\
$18: 1 \mathrm{n}-9$ (Oleic acid) & $17.80 \pm 2.75^{\mathrm{b}}$ & $99.87 \pm 8.60^{\mathrm{a}}$ \\
$18: 1 \mathrm{n}-7$ (cis-Vaccenic acid) & $6.74 \pm 1.06^{\mathrm{b}}$ & $51.84 \pm 6.31^{\mathrm{a}}$ \\
$18: 2 \mathrm{n}-6$ (Linoleic acid) & $518.92 \pm 39.93^{\mathrm{b}}$ & $3462.87 \pm 189.8^{\mathrm{a}}$ \\
$18: 3 \mathrm{n}-3$ (alpha-Linolenic acid) & $242.60 \pm 19.04^{\mathrm{b}}$ & $987.74 \pm 34.42^{\mathrm{a}}$ \\
$20: 0$ (Arachidic acid) & $7.51 \pm 0.69^{\mathrm{b}}$ & $180.52 \pm 21.45^{\mathrm{a}}$ \\
$22: 0$ (Behenic acid) & $5.66 \pm 0.67^{\mathrm{b}}$ & $52.91 \pm 5.89^{\mathrm{a}}$ \\
$20: 4 \mathrm{n}-6$ (Arachodonic acid) & $9.00 \pm 0.94^{\mathrm{b}}$ & $127.94 \pm 8.80^{\mathrm{a}}$ \\
$20: 5 \mathrm{n}-3$ (Eicosa-pentaenoic acid) & $20.49 \pm 1.75^{\mathrm{b}}$ & $175.60 \pm 11.32^{\mathrm{a}}$ \\
Sum of saturated fatty acids & $256.49 \pm 21.08^{\mathrm{b}}$ & $2600.78 \pm 148.47^{\mathrm{a}}$ \\
Sum of monounsaturated fatty acids & $24.54 \pm 2.95^{\mathrm{b}}$ & $151.71 \pm 10.67^{\mathrm{a}}$ \\
Sum of polyunsaturated fatty acids & $796.41 \pm 44.2^{\mathrm{b}}$ & $4754.15 \pm 193.50^{\mathrm{a}}$ \\
\hline
\end{tabular}

a,b Mean in the same row with different superscript differ significantly at $\mathrm{p} \leq 0.05$

Table 5. Initial, final body weight gain and feed efficiency ratio in rats fed orally with different parts of artichoke extracts

\begin{tabular}{lccccc}
\hline Groups & $\begin{array}{c}\text { Initial body } \\
\text { weight }\end{array}$ & $\begin{array}{c}\text { Final body } \\
\text { weight }\end{array}$ & $\begin{array}{c}\text { Body weight } \\
\text { Gain }\end{array}$ & Total feed intake & $\begin{array}{c}\text { Feed efficiency } \\
\text { ratio }\end{array}$ \\
\hline Control negative & $167.5 \pm 7.6^{\mathrm{b}}$ & $194.5 \pm 6.6^{\mathrm{a}}$ & 27.0 & $462.7 \pm 26.0^{\mathrm{a}}$ & $5.84 \pm 0.2^{\mathrm{a}}$ \\
Control positive & $170.3 \pm 8.0^{\mathrm{ab}}$ & $177.0 \pm 7.0^{\mathrm{b}}$ & 6.7 & $348.6 \pm 28.3^{\mathrm{b}}$ & $1.92 \pm 0.6^{\mathrm{d}}$ \\
Group 1 & $181.7 \pm 8.6^{\mathrm{a}}$ & $191.8 \pm 7.9^{\mathrm{a}}$ & 10.1 & $450.4 \pm 31.3^{\mathrm{a}}$ & $2.42 \pm 0.2^{\mathrm{c}}$ \\
Group 2 & $182.3 \pm 9.1^{\mathrm{a}}$ & $197.8 \pm 8.2^{\mathrm{a}}$ & 15.5 & $445.6 \pm 31.1^{\mathrm{a}}$ & $3.47 \pm 4.7^{\mathrm{b}}$ \\
Group 3 & $171.8 \pm 7.8^{\mathrm{b}}$ & $193.8 \pm 8.1^{\mathrm{a}}$ & 22.0 & $420.03 \pm 1.2^{\mathrm{a}}$ & $5.24 \pm 0.2^{\mathrm{d}}$ \\
Group 4 & $180.5 \pm 8.6^{\mathrm{a}}$ & $192.3 \pm 7.9^{\mathrm{a}}$ & 12.8 & $455.9 \pm 30.8^{\mathrm{a}}$ & $2.81 \pm 0.6^{\mathrm{c}}$ \\
Group 5 & $175.3 \pm 6.7^{\mathrm{b}}$ & $192.1 \pm 8.4^{\mathrm{a}}$ & 16.8 & $450.5 \pm 22.3^{\mathrm{a}}$ & $3.73 \pm 0.2^{\mathrm{b}}$ \\
Group 6 & $173.2 \pm 7.6^{\mathrm{b}}$ & $198.3 \pm 9.5^{\mathrm{a}}$ & 25.1 & $430.4 \pm 15.4^{\mathrm{a}}$ & $5.83 \pm 0.4^{\mathrm{a}}$ \\
\hline
\end{tabular}

a,b.c.d Mean in the same column with different superscript differ significantly at $p \leq 0.05$.

Group 1 fed on basal diet and $2 \mathrm{ml}$ orally/ day $200 \mathrm{mg} / \mathrm{kg}$ body weight from artichoke leaves Group 2 fed on basal diet and $2 \mathrm{ml}$ orally/ day $400 \mathrm{mg} / \mathrm{kg}$ body weight from artichoke leaves Group 3 fed on basal diet and $2 \mathrm{ml}$ orally/ day $600 \mathrm{mg} / \mathrm{kg}$ body weight from artichoke leaves Group 4 fed on basal diet and $2 \mathrm{ml}$ orally/ day $200 \mathrm{mg} / \mathrm{kg}$ body weight from artichoke head Group 5 fed on basal diet and $2 \mathrm{ml}$ orally/ day $400 \mathrm{mg} / \mathrm{kg}$ body weight from artichoke head Group 6 fed on basal diet and $2 \mathrm{ml}$ orally/ day $600 \mathrm{mg} / \mathrm{kg}$ body weight from artichoke head

Effect of the different parts of artichoke extracts on the glucose level and lipid parameter in diabetic and cholesterolemic rats:

Table (6) showed that the effect of the different parts (leaves and head) of the artichoke extracts at 200, 400 and $600 \mathrm{mg} / \mathrm{kg}$ b.wt ratios on the glucose level, total lipids, triglyceride, total cholesterol, high density lipoprotein and low density lipoprotein in hyperlipidemic and diabetic rats groups during four weeks. The results showed that the serum total lipid decreased significantly when the hyperlipidemic rats were fed on $600 \mathrm{mg} / \mathrm{kg}$ b.wt from leaves and head ( 390.2 and $350.5 \mathrm{mg} / \mathrm{dl}$, respectively) after 4 weeks. On the same parallel, when rats were fed orally on diets containing $600 \mathrm{mg} / \mathrm{kg}$ from artichoke leaves and heads, the serum total cholesterol and triglycerides were significantly decreased to 135.2 and $130.0 \mathrm{mg} / \mathrm{dl}$ for cholesterol and 145.3 and $136.8 \mathrm{mg} / \mathrm{dl}$ for triglycerides, respectively, compared to the control positive at 238.8 and $235.8 \mathrm{mg} / \mathrm{dl}$. Results showed that the part (head) of the artichoke extracts was more effective for serum lipid patterns than the part (leaves) artichoke which was due to the head artichoke rich in polyphenols and flavonoids content. Also, the effectiveness of head artichoke was clear in triglycerides then total cholesterol. 
Table 6. Effect of the different parts artichoke extracts on glucose level and lipid parameter in diabetic and cholesterolemic rats $(\mathbf{m g} / \mathbf{d l})$

\begin{tabular}{lcccccc}
\hline Groups & Total lipids & Triglyceride & $\begin{array}{c}\text { Total } \\
\text { cholesterol }\end{array}$ & $\begin{array}{c}\text { HDL } \\
\text { cholesterol }\end{array}$ & $\begin{array}{c}\text { LDL } \\
\text { cholesterol }\end{array}$ & Total glucose \\
\hline Control negative & $326.3 \pm 17.3^{\mathrm{d}}$ & $103.8 \pm 8.6$ & $120.8 \pm 8.3^{\mathrm{d}}$ & $49.5 \pm 5.8^{\mathrm{a}}$ & $60.5 \pm 3.0^{\mathrm{d}}$ & $128.0 \pm 8.0^{\mathrm{d}}$ \\
Control positive & $605.0 \pm 25.7^{\mathrm{a}}$ & $235.8 \pm 15.4^{\mathrm{a}}$ & $238.8 \pm 14.3^{\mathrm{a}}$ & $23.0 \pm 1.9^{\mathrm{b}}$ & $168.3 \pm 8.5^{\mathrm{a}}$ & $250.0 \pm 16.5^{\mathrm{a}}$ \\
Group 1 & $566.0 \pm 23.9^{\mathrm{b}}$ & $212.0 \pm 8.3^{\mathrm{b}}$ & $172.5 \pm 8.1^{\mathrm{b}}$ & $27.3 \pm 1.9^{\mathrm{b}}$ & $102.9 \pm 5.3^{\mathrm{b}}$ & $222.3 \pm 12.2^{\mathrm{b}}$ \\
Group 2 & $471.3 \pm 22.5^{\mathrm{c}}$ & $194.8 \pm 8.9^{\mathrm{c}}$ & $163.0 \pm 8.2^{\mathrm{c}}$ & $37.5 \pm 1.8^{\mathrm{c}}$ & $86.6 \pm 5.4^{\mathrm{c}}$ & $171.5 \pm 11.7^{\mathrm{c}}$ \\
Group 3 & $390.2 \pm 19.2^{\mathrm{d}}$ & $145.3 \pm 7.5^{\mathrm{d}}$ & $135.2 \pm 5.9^{\mathrm{d}}$ & $40.2 \pm 2.1^{\mathrm{a}}$ & $67.3 \pm 4.3^{\mathrm{d}}$ & $145.2 \pm 8.3^{\mathrm{d}}$ \\
Group 4 & $511.6 \pm 15.7^{\mathrm{b}}$ & $200.1 \pm 5.4^{\mathrm{b}}$ & $168.3 \pm 4.6^{\mathrm{b}}$ & $30.0 \pm 21.9^{\mathrm{b}}$ & $95.4 \pm 3.8^{\mathrm{b}}$ & $190.5 \pm 9.2^{\mathrm{b}}$ \\
Group 5 & $440.5 \pm 22.4^{\mathrm{c}}$ & $182.0 \pm 8.9^{\mathrm{c}}$ & $160.0 \pm 8.1^{\mathrm{c}}$ & $39.75 \pm 2.1^{\mathrm{c}}$ & $83.9 \pm 5.2^{\mathrm{c}}$ & $166.0 \pm 12.2^{\mathrm{c}}$ \\
Group 6 & $350.5 \pm 21.9^{\mathrm{d}}$ & $136.8 \pm 8.6^{\mathrm{d}}$ & $130.0 \pm 8.0^{\mathrm{d}}$ & $42.0 \pm 2.6^{\mathrm{a}}$ & $62.7 \pm 4.3^{\mathrm{d}}$ & $140.3 \pm 12.3^{\mathrm{d}}$ \\
\hline
\end{tabular}

a,b.c.d Mean in the same column with different superscript differ significantly at $\mathrm{p} \leq 0.05$

Artichoke extracts and some of their pure phenolic constituents have been tested for their defensive role in the regulation of oxidative damage to biological molecules (proteins, lipids and DNA) caused by free radicals such as $\mathrm{RCOO}$ and/or $\mathrm{OH}$ and their mechanisms of action using the $\beta$-carotene/ linoleate and deoxyribose, metmyoglobin assay, respectively (Lattanzio et al., 2005).

The results from HDL- cholesterol and LDLcholesterol in hyperlipidemic and diabetic rats fed orally on the different parts (leaves and head) of the artichoke extracts at 200, 400 and $600 \mathrm{mg} / \mathrm{kg}$ b.wt ratios are reported in the same Table. From the results, it could be observed that the HDL- cholesterol was significantly increased in hyperlipidemic and diabetic rats fed orally on leaves and head artichoke at 400 and $600 \mathrm{mg} / \mathrm{dl}$ ratios. However, the hyperlipidemic and diabetic rats fed orally on the different parts (leaves and head) of the artichoke extracts at 400 and $600 \mathrm{mg} / \mathrm{kg} \mathrm{b}$. wt ratios significantly lowered in LDL- cholesterol from 168.3 $\mathrm{mg} / \mathrm{dl}$ in the control positive to 67.3 and $62.7 \mathrm{mg} / \mathrm{dl}$ in the leaves and head artichoke at $600 \mathrm{mg} / \mathrm{kg} \mathrm{b}$. wt ratio. Although the most important active compound of Cynarascolymus L., cynarin, is present in the whole plant, the major concentration is found in the artichoke. For this reason, most of the natural medicines obtained from this plant are prepared from leaves and head. Cynarin is found in the whole plant and besides it is considered as one of the main active chemical compounds. Technically, cynarin is a caffeolquinic acid and concentrates in major degree in the artichoke (Speroni, 2003).

From the results, it could be noticed that the hyperlipidemic and diabetic rats fed orally on 400 and $600 \mathrm{mg} / \mathrm{kg} \mathrm{b}$. wt ratios head artichoke significantly decreased in serum glucose blood level (166.0 and $140.3 \mathrm{mg} / \mathrm{dl}$ ), followed by hyperlipidemic and diabetic rats fed orally on 400 and $600 \mathrm{mg} / \mathrm{kg}$ b. wt ratios leaves artichoke (171.5 and $145.2 \mathrm{mg} / \mathrm{dl})$. It is clear that feeding orally of the different parts (leaves and head) artichoke extracts at $600 \mathrm{mg} / \mathrm{kg} \mathrm{b}$. wt ratios resulted in a reduced serum glucose level. Artichokes are very high in fiber, which is crucial for numerous functions in the body. These decreased may be caused by the high amount of fiber found in artichokes that has the ability to help keep blood sugar levels stable, avoiding spikes and dips in insulin that can lead to serious problems for diabetics. The fiber in artichokes allows the absorption of glucose more slowly in the blood, and since fiber is a substance that can be digested and does not require insulin, fiber does not count towards the amount of carbohydrates or glucose one consumes.

From the obvious results, it could be noticed that the different parts (leaves and head) of artichoke extracts are rich in phenolic acids and flavonoids compounds. These contents could be responsible in the prevention of diabetic level and lipid parameters and lowering them. In conclusion, among the two fractions of artichoke the (leaves and head) was found to contain the highest content of flavonoids and phenolic of free phenolic extract. Significant difference was observed in the total flavonoids of the different parts of artichoke. These compounds in artichoke help to lower blood cholesterol level by lowering low density lipoprotein or bad cholesterol levels. Artichoke is also beneficial for other heart health benefits like reducing inflammation and blood glucose.

\section{REFERENCE}

Adom, K.K and R.H. Liu. 2002. "Antioxidant activity of grains", Journal of Agriculture and Food Chemistry. 50: 6182-6187. 
Adzet, C.J. and L.J. Carlos, 1987. Hepatoprotective activity of polyphenolic compounds from Cynarascolymus against $\mathrm{CCl} 4$ toxicity in isolated rat hepatocytes. J Nat Prod. 50: 612-7.

Allain, C.C., L.S. Poon, C.S. Chan, W. Richamand and P.C. Fu. 1974. Enzymatic determination of total serum cholesterol.Clin. Chem. 20(4): 470.

Andersen, C., S. Rayalam, M.A. Della-Fera and C.A. Baile. 2010. Phytochemicals and adipogenesis.Biofactors. 36: 415-422.

AOAC. 2010. Official Methods of Analysis of Association of Official Chemists. $18^{\text {th }}$ Ed., Washington, D.C.,USA.

Bianco, V. 2005. Present situation and future potential of artichoke in the Mediterranean basin. ActaHort. 681:3955.

Burstein, M., 1970. HDL Cholesterol determination after separation of high density lipoprotein. Lipids Res. 11:583589.

Ceccarelli, N., M. Curadi, P. Picciarelli, L. Martelloni, C. Sbrana and M. Giovannetti. 2010. Globe artichoke as functional food. Mediterranean J. NutrMetab.3:197-201.

Clifford, M. and J. Brown. 2006. Dietary flavonoids and health, broadening the perspective. In: Andersen $\mathrm{O}$ \& Markham K Eds. Flavonoids: Chemistry, biochemistry and applications. CRC Press, Boca Raton: USA.

Efterpi, C., B. Eleftherios and F. Panagiota. 2012. Nutritional and Functional Properties of Cynara Crops (Globe Artichoke and Cardoon) and Their Potential Applications: A Review. Int J App Sci Technol. 2: 64-70.

Fossati, P. and L. Prencipe. 1982. The determination of triglyceride using enzymatic methods. Clin. Chem. 28:2077.

Fratianni, F., M. Tucci, M. De Palma, R. Pepe and F. Nazzaro. 2007. Polyphenolic composition in different parts of some cultivars of globe artichoke (CynaracardunculusL. var. scolymus(L.) Fiori). Food Chem. 104: 1282-86.

Fruchart, J.C., 1982. LDL Cholesterol determination after separation of low density lipoprotein. Rev. Fr.Des Lab. 103: 7-17.

Fukumoto, L.R. and G. Mazza. 2000. Assessing antioxidant and proxidant activities of phenolic compounds. Journal of Agricultural and Food Chemistry. 48: 3597-3604.

Gould, A.L., G.M. Davies, E. Alemao, D.D. Yin and J.R. Cook. 2007. Cholesterol reduction yields clinical benefits: meta-analysis including recent trials. Clin. Ther. 29: 778794.

Hosseinzadeh, M., F. Shekari, M. Janmohammadi and N. Sabaghnia. 2013. Effect of sowing date and fliar application of salicylia acid on forage yields and quality of globe artichoke (cynarascolymus L.) Annales. 8: 50- 59.

Jimenez-Escrig, A., L. Dragsted, B. Daneshvar, R. Pulido and F. Saura-Calixto, 2003. In vitro antioxidant of edible artichoke (cynarascolymus L.) and effect of biomarkers of antioxidant in rats. J. of Agriculture and Food Chemistry. $51: 5540-5545$.
Joseph, J.D. and R.G. Ackman. 1992. Capillary column gaschromatographic method for analysis of encapsulated fish oils and fish oil ethyl-esters e collaborative study. J. of AOAC International. 75: 488- 506.

Joy, J.F. and S.L. Haber. 2007. Clinical uses of artichoke leaf extract. Am. J. Health Syst. Pharm. 64: 1906-1909.

Justesen, U. and P. Knuthsen. 2001. Composition of flavonoids in fresh herbs and calculation of flavonoid intake by use of herbs in traditional Danish dishes. Food Chemistry. 73: 245-250.

Juzyszyn, Z., B. Czerny, A. Pawlik and M. Drozdzik. 2008. The effect of artichoke (CynarascolymusL.) extract on ROS generation in HUVEC cells. Phytother. Res. 22: 1159-1161.

Knight, J.A., S. Anderson and J.M. Rowle. 1972. Chemical bases of the sulpfo-phospho vanillin reaction for estimating total serum lipids. J. Clin. Chem. 18 :199-204.

Kucukgergin, C., A.F. Aydin, G.O. Ozdemirler, G. Mehmetcik, N. Kocar-Toker and M. Uysal. 2010. Effect of artichoke leaf extract on hepatic and cardiac oxidative stress in rats fed on high cholesterol diet. Biol Trace Elem Res., 135: 264-74.

Kukic, J., V. Popovic, S. Petrovic, P. Mucaji, A. Ciric, D. Stojkovic and M. Sokovic, 2008. Antioxidant and antimicrobial activity of Cynaracardunculus extracts. Food Chemistry. 107:861-868.

Küskü-Kiraz, Z., G. Mehmetçik, S. Dogru-Abbasoglu and M. Uysal. 2010. Artichoke leaf extract reduces oxidative stress and lipoprotein dyshomeostasis in rats fed on high cholesterol diet. Phytother. Res. 24: 565- 570.

Lattanzio, V., 1982. Composizionevalorenutritivo e terapeutico del carciofo, InformatoreAgrario XXXVIII, 1. 18727-31.

Lattanzio, V., N. Cicco and V. Linsalata. 2005. Antioxidant activities of artichoke phenolics. ActaHorticulturae. 681: 421-428.

Lattanzio, V., A.K. Paul, L. Vito and C. Angela. 2009. Globe artichoke: a functional food and source of nutraceutical ingredients. J Funct Foods. 1: 131-44.

Llorach, R., J. Espin, B.F. Tomas and F. Ferreres. 2002. Artichoke (CynarascolymusL.) byproducts as a potential source of health-promoting antioxidant phenolics. J. Agric. Food Chem. 50: 3458-3464

Lutz, M., C. Henriquez and M. Escobar. 2011. Chemical composition and antioxidant properties of mature and baby artichokes (cynarascolymus L.) raw and cooked. Journal of Food Composition and Analysis. 24: 49- 54.

Madar, Z. 1983. Effect of brown rice and soybean dietary fiber on the control, glucose and lipid metabolism in diabetic rats. Am. M. J. Clin. Nutr. 388-393.

McKenney, J.M. 2001. Pharmacotherapy of dyslipidemia. Cardiovasc. Drugs Ther. 15: 413-422.

Mulvihill, E.E. and M.W. Huff. 2010. Antiatherogenic properties of flavonoids: implications for cardiovascular health. Can. J. Cardiol. 26: 17A-21A. 
Pandino, G., S. Lombardo, G. Mauromicale and G. Williamson, 2011. Profile of polyphenols and phenolic acids in bracts and receptacles of globe artichoke (Cynaracardunculus var. scolymus) germplasm. J. Food Compos Anal. 24: 148-53.

Pandino, G., S. Lombardo and G. Mauromicale. 2013. Globe artichoke leaves and floral stems as a source of bioactive compounds. Industrial Crops and Products. 44: 44-49.

Perez Garcia, F., T. Adzet and S. Canigueral. 2000. “Activity of artichoke leaf extract on reactive oxygen species in human leukocytes", Free Radical Research. 33: 661-665.

Pinto, M.S., F.M. Lajalo and M.I. Genovese. 2008. Bioactive compounds and quantification of total ellagic acid in strawberries (FragariaxananassaDuch) Food Chemistry. 107: 1629-1635.

Rottenberg, A. and D. Zohary, 1996. "The wild ancestry of the cultivated artichoke." Genet. Res. Crop Evol. 43: 53-58.

SAS System for Windows (Statistical Analysis System). 2008. Version 9.2. Cary, USA: SAS Institute Inc.

Shen, Q., Z. Dai and L. Yanbin. 2010. Rapid determination of caffeoylquinic acid derivatives in cynarascolymus L by ultrafast liquid chromatography/ tandem mass spectrometry based on a fused core C18 column. J. of separation sci. 33: 3152-3158.

Shimoda, H., K. Ninomiya, N. Nishida, T. Yoshino, T. Morikawa, H. Matsuda and M. Yoshikawa. 2003. Antihyperlipidemic sesquiterpenes and new sesquiterpene glycosides from the leaves of artichoke (CynarascolymusL.): structure requirement and mode of action. Bioorg. Med. Chem. Lett. 13: 223-228.
Sonnante, G., D. Pignone and K. Hammer. 2007. The domestication of artichoke and cardoon: from Roman times to the genomic age. Ann Bot. 100: 1095-1100.

Sosulski, F., K. Krygier and L. Hogge. 1982. "Free esterified and insoluble-bound phenolic acids. 3. Composition of phenolic acids in cereal and potato flours", J. of Agricultural and Food Chemistry. 30: 337-340.

Speroni, E., R. Cervellati, P. Govoni, S. Guizzardi, C. Renzulli and M.C. Guerra. 2003. Efficacy of different Cynarascolymus preparations on liver complaints. Journal of Ethnopharmacol. 86(2-3):203-11.

Tietz, N.W., 1986. Text Book of Clinical Chemistry. P.796.Saunders, W. B. Co., London-Pheladelphia.

Wang, M., J.E. Simon, I.F. Aviles, K. He, Q.Y. Zheng and Y. Tadmor. 2003. Analysis of antioxidative phenolic compounds in artichoke (CynarascolymusL.). J. Agric. Food Chem. 51: 601-608.

Yeh, Y.F., R.C. Hoseney and D.R. Lineback. 1980. "Changes in wheat flour pentosans as a result of doughmixing and oxidation", Cereal Chemistry. 57: 144-148.

Zapolska, D.D., D.A. Zapolski, M. Naruszewicz, A. Siennicka, B. Krasnodebska and B. Koldziej. 2002. Protective properties of artichoke (Cynarascolymus) against oxidative stress induced in cultured endothelial cells and monocytes. Life Sci. 71: 2897-2908.

Zhishen, J., T. Mengcheng and W. Jianming. 1999. "The determination of flavonoid contents in mulberry and their scavenging effects on superoxide radicals", Food Chemistry. 64: 555-559. 


\section{الملخص العربي \\ الخرشوف كأداة لمضادات الأكسدة الطبيعية لخفض السكر وقياسات دهون الدم

$$
\text { فايزه مساعد محمد الصبحي }
$$

أجريت هذه الدراسة لتقييم أجزاء مختلفة من الخرشوف وكان تفريد المركبات الرئيسية من الأحماض الدهنية هي

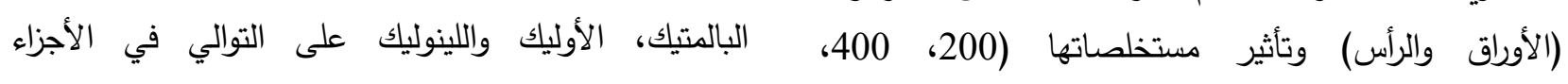
600ملجم/ كجم من وزن جسم فئران التجارب)، ومضادات المختلفة من الخرشوف. الأكسدة الطبيعية على ارتفاع الكوليسترول وسكر الدم في أظهرت النتائج في نهاية التجربة البيولوجية التي إستمرت الفئران. وتم تقدير التركيب الكيميائي، وتحليل الأحماض لمدة أربعة أسابيع أن رأس الخرشوف كان لها تأثير في

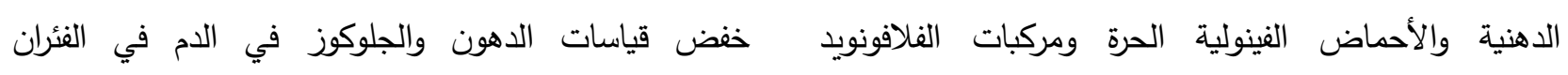
والمرتبطة منهم. وأظهرت النتائج أن أعلى كمية من البروتين المصابة بارتفاع الكوليسترول وسكر الدم تليها أوراق الخام وأقل من الألياف الخام سجلت في الرأس للخرشوف الخرشوف. هذاقد يكون بسبب أن رأس الخرشوف تحتوي 17.85 و 29.61 \% \%على التوالي في حين سجلت الأوراق على كميات كبيرة من مضادات الأكسدة الطبيعية ونسبة 9.54 ٪ من البروتين، وكان أعلى كمية من الألياف الخام منخفضة في الألياف الخام في حين كانت أوراق الخرشوف 32,41 ٪. إحتوى الخرشوف (الرأس) على نسبة أعلى من أعلى فينسبة الألياف الخام وأقل في مضادات فئ الأكسدة مجموع المركبات الفينولية الحرة (14.16 ملجم / جم وزن الطبيعية. لذلك يمكن أن توصي الدراسة بالتغذية بالأجزاء جاف)، يليه الخرشوف (أوراق) الذي تضمن فقط (9.06 المختلفة من الخرشوف لما لها من فائدة غذائية صحية، ملجم / جم وزن جاف). من ناحية أخرى إنخفضت المركبات وكخافض لسكر الدم وقياسات الدهون. الفينولية المرتبطة في كل من الأوراق وأجزاء رأس الخرشوف. 